\title{
Within-subject foot motion variability in patients with Rheumatoid Arthritis
}

\author{
Lindsey Hooper ${ }^{1 *}$, Lucy Gates ${ }^{1}$, Lyndsey Goulston ${ }^{1}$, Cathy Bowen ${ }^{1}$, Christopher Edwards', Nigel Arden² \\ From Society of Chiropodists and Podiatrists Annual Conference 2010 \\ Bournemouth, UK. 21-23 October 2010
}

\section{Introduction}

Multi-segment three-dimensional analysis is a complex yet rapidly evolving methodology in podiatric mechanical research. The purpose of this study was to explore the within-subject foot motion variability (MoVa) during the stance phase of gait.

\section{Methods}

A 3D motion analysis system was used to collect gait data for 5 healthy participants and 5 patients with RA. The oxford foot model was used to characterise dynamic foot \& ankle kinematics and spatio-temporal parameters. Inter-segmental motions of interest were defined as tibia-rearfoot and rearfoot-forefoot. The main outcome of interest was within-subject MoVa, expressed as mean standard deviation (SD).

\section{Results}

MoVa ranged from 0.94- 2.33SD and was similar for both groups. Increased MoVa was largely accounted for by rearfoot variance. There is a trend towards increased forefoot MoVa in the RA group (RA 0.65-1.78, Control 0.34-0.9). No single episode during the stance phase had greater variability than any other.

\section{Discussion}

MoVa rather than a particular gait event may be an alternative outcome warranting further investigation. These results suggest care should be taken when assuming mean within-subject MoVa in mechanical analyses. This preliminary work suggests that greater forefoot MoVa may occur in RA participants. This pilot investigation provides useful preliminary data to inform future studies.

${ }^{1}$ University of Southampton, Southampton, UK
Author details

${ }^{1}$ University of Southampton, Southampton, UK. ${ }^{2}$ University of Oxford, Oxford, UK.

Published: 20 December 2010

doi:10.1186/1757-1146-3-S1-P7

Cite this article as: Hooper et al:: Within-subject foot motion variability in patients with Rheumatoid Arthritis. Journal of Foot and Ankle Research 2010 3(Suppl 1):P7.
Submit your next manuscript to BioMed Central and take full advantage of:

- Convenient online submission

- Thorough peer review

- No space constraints or color figure charges

- Immediate publication on acceptance

- Inclusion in PubMed, CAS, Scopus and Google Scholar

- Research which is freely available for redistribution
() Biomed Central
Full list of author information is available at the end of the article

C Biomed Central 